\title{
Role of Self-Esteem and General Self-Efficacy in Teachers' Efficacy in Primary Schools
}

\author{
Azizuddin Khan', Eleni Fleva'2 ${ }^{2}$, Tabassum Qazi ${ }^{3}$ \\ ${ }^{1}$ Psychophysiology Laboratory, Department of Humanities and Social Sciences, Indian Institute of Technology \\ Bombay, Mumbai, India \\ ${ }^{2}$ Department of Theoretical \& Applied Linguistics, School of English, Aristotle University of Thessaloniki, \\ Thessaloniki, Greece \\ ${ }^{3}$ Department of Psychology, S.N.D.T University, Mumbai, India \\ Email: khanaziz@iitb.ac.in, elenifleva@enl.auth.gr, tabbu11@gmail.com
}

Received 29 December 2014; accepted 17 January 2015; published 23 January 2015

Copyright (C) 2015 by authors and Scientific Research Publishing Inc.

This work is licensed under the Creative Commons Attribution International License (CC BY). http://creativecommons.org/licenses/by/4.0/

(c) (i) Open Access

\begin{abstract}
Teachers' self-efficacy is assumed to be affected by self-esteem and teachers' general self-efficacy. Self-esteem is considered to be a trait reflecting an individual's characteristic affective evaluation of self (Gist \& Mitchell, 1992). The current study explores the factors that would affect teachers' efficacy in cultural context. In the current study 200 teachers participated from various public schools. Multivariate analysis of variance and correlational analysis were employed to understand the effect of self-esteem and self-efficacy on teachers' efficacy. The results indicated significant relationship between teachers' efficacy and general self-efficacy and self-esteem. It was found that low self-esteem and low general self-efficacy led to low teachers' efficacy and consequently substandard performance in the class. On the contrary, high teachers' efficacy was a reflection of high self-esteem and high general self-efficacy. Self-esteem influenced only in decision making, perceived education self-efficacy, perceived disciplinary self-efficacy, ability to get cooperation from community, and in the development of positive school environment of teachers' efficacy. General self-efficacy influenced all the components of teachers' efficacy except decision making and ability to influence school council/authorities. In the study, it was observed that self-esteem significantly influenced teachers' efficacy.
\end{abstract}

\section{Keywords}

Cognitive Process, Primary Education, Self-Efficacy, Self-Esteem, Teachers' Efficacy 


\section{Introduction}

According to Bandura (1997) self-efficacy is the "beliefs in one's capabilities to organise and execute the courses of action required producing given attainments" (p. 3). That refers not to the actually abilities of someone's to perform certain tasks but rather to their self-perception of being able to perform certain tasks under given conditions (Evers et al., 2002). The degree of self-efficacy is the product of both external (i.e., environment) as well as internal (i.e., cognitive, affective, biological and behavioural) factors (Evers et al., 2002). These factors appear to be interrelated and develop individual's personality. Henson (2001) pointed out that humans are not the product of either biology or environment but rather the product of the influence of both external and internal factors.

Self-efficacy appears to strongly relate to Rotter's (1966) locus of control theory. This theory supports that people differ according to the level of responsibility they perceive they acquire upon events, consequences and opportunities in their lives (Hogg \& Vaughan, 2002). Individuals with an internal locus of control believe that things in life are the product of their own behaviours and choices and are characterised by high degree of control upon them (Rotter, 1966). Contrary, individuals with an external locus of control believe that they have low or no control upon things in their lives as these happen due to external powers or agents, such as luck (Rotter, 1966).

The importance of self-efficacy appears to depend on its ability to affect human's choices and behaviours (Henson, 2001). Indeed, Bandura (1997) supported that self-efficacy plays a key role in the development of human achievements and motivations. Bandura's work strongly supports the notion that human's behaviours, their motivations as well as the outcome of their actions (success or failure) are the product of their self-efficacy (1982, 1986, 1993, 1996, and 1997). This has also been supported experimentally. For example, efficacy has been found to strongly link to phobias (Bandura, 1983) to depression (Davis \& Yates, 1982) as well as to addictive behaviours such as smoking (Garcia et al., 1990). Efficacy degree also affects human motivation (Maehr \& Pintrich, 1997; Pintrich \& Schunk, 1996) as well as emotions (Pajares, 1997).

Since Bandura's (1997) social cognitive theory in relation to self-efficacy a number of scholars examined efficacy under educational settings. Teacher efficacy is referred to "the extent to which the teacher believes he or she has the capacity to affect student performance” (Bergman, McLaughlin, Bass et al., 1977: p. 137). The importance of examining teacher efficacy lies to the extent of influence it exerts upon student's performance. Indeed, studies have shown that student's achievements appear to be the product of their educators' efficacy degree (e.g., Ross, 1992). Woolfolk and Hoy (1990) mentioned that "Researchers have found few consistent relationships between characteristics of teachers and the behaviour or learning of students. teachers' sense of efficacy is an exception to this general rule" (p. 81). Indeed, studies have reported greater student's achievements when they had been taught by efficacious teachers compared to students from other classes (Watson, 1991). Additionally, efficacious teachers appear to have a positive effect upon student’s motivation (Midgley et al., 1989) as well as upon the development of their own self-efficacy degree (Anderson et al., 1988). Berman and McLaughlin (1977) found a strong positive correlation between student's performance and teachers' efficacy level.

Efficacious (than non-efficacious) teachers appear to exert greater positive influence upon students due to their attitude and behaviour. That is, efficacious teachers tend to be less judgmental with students' mistakes (Gibson \& Dembo, 1984) and they support more students from low socioeconomic status (Meijer \& Foster, 1988; Podell \& Soodak, 1993). They also appear to be more open to new teaching methods (Allinder, 1994; Guskey, 1988; Stein \& Wang, 1988) while they are more committed to their duties (Coladarci, 1992). Efficacious teachers also appear to have better organisational and management skills (Gibson \& Dembo, 1984; Saklofske et al., 1988; Woolfolk et al., 1990) than non-efficacious ones. In contrast to the positive outcomes derived from efficacious teachers, research have shown that low efficacy teachers motivate students less and appear less persistent towards student's learning (Podell \& Soodak, 1993).

According to Ashton and Webb (1982) efficacious teachers are the product of two significant variables. The first one is the degree of teachers' teaching efficacy. This constitutes teachers' beliefs in their abilities to influence student's performance regarding other external factors (e.g., student's personal environment) (Ashton \& Webb, 1982). The second one is teachers' personal efficacy which is teachers' beliefs in their own personal abilities to positively affect student's learning (Ashton \& Webb, 1982). Woolfolk and Hoy (1990) agreed that teaching efficacy is an important determination of teachers' efficacy but they added an additional dimension to teachers' personal efficacy. They pointed out that teachers' personal efficacy constitutes of teachers' personal responsibility regarding student's both positive and negative outcomes (Woolfolk \& Hoy, 1990). Both personal 
efficacy and teaching efficacy appear to be important influential variables towards student's performance. Ashton and Webb (1986) found that teaching efficacy affected student's mathematics achievements by $24 \%$ while personal efficacy affected their language performance by $46 \%$.

Similarly, there is positive and direct relationship between self-esteem and person efficacy. Self-esteem refers individual's evaluation of himself/herself. It is the "personal judgment of worthiness that is expressed in the attitude the individual holds toward him" (Kohn, 1994: p. 273). Self-esteem is important factors for job satisfaction, and job performance (Bowles \& Gintis, 1976; Bowles et al., 2001). Self-efficacy is necessary for a healthy self-esteem (Vancouver Community Network, 1998: p. 1). If a person does not feel worthy of love and respect of others, he/she may not develop positive image of self. Research shows that self-efficacy influence academic performance , motivation, learning and achievement (Pajares, 1996; Schunk, 1985).

Self-efficacy beliefs influence task choice, effort, persistence, resilience and achievement (Bandura, 1997; Schunk, 1985). Self-efficacy, self-regulation and cognitive strategy are positively related and predictor of achievement (Pintrich \& De Groot, 1990).

Self-efficacy closely related to persistence, achievement and learning. These all three words perfectly fit in the area of achievement related behavior or academic behavior. Teaching is the good example of all these motivation concepts.

The term teachers' efficacy means the extent to which teachers believe he or she has a capacity to affect student learning and achievement. Teachers' sense of efficacy was first conceptualized in two Rand Corporation evaluation studies (1976). Teacher sense of efficacy is positively related to achievement behavior, improved student performance (Berman et al.,199, p. 137), motivation (Midgley et al., 1989) and students own sense of efficacy (Anderson et al., 1988), and exhibit greater levels of planning, organization and enthusiasm (Allinder, 1994) himself/herself, no matter how much one had accomplished in the past.

Self-esteem has broadly been used as a measure of well-being, feeling about self (positive or negative), while self-efficacy has been used a predictor of behavior (Wenzel, 1993). Evidence has proved that self-efficacy has a strong effect on the task as person will undertake (such as teaching), the effort they bring to bear on these task, his/her perseverance, their response to setbacks, and has been found to be influential in change across a wide range of behaviours (Bandura, 1997). Self-efficacy is a judgement about his own ability to follow a needed or desired course of action, "I can or cannot do a particular thing or action".

Someone with high self-esteem has a lot of confidence, but there is a difference in self-esteem and self-confidence, for example, a person has high self-esteem but they may or may not be good in ball dancing or volley ball, or may have low self-efficacy for ball dancing, but that doesn't means that they have low self-esteem. Self-esteem is a permanent internal feeling while self-efficacy is feeling that depends upon performance at hand. Based on literature review, the following questions were identified for the current study.

1) To investigate whether GSE (generalized self-efficacy) can be used as a predictor of teachers' efficacy in academic setting?

2) To determine which (GSE or self-esteem) variable play a role in teachers' self-efficacy or student esteem and efficacy development?

3) Whether there is any role of education level to enhance in teacher efficacy behaviour?

4) Research is needed that to what extent GSE beliefs extend one domain to another?

The following objectives were formulated to find out answer of the above mentioned questions. The present research examines the relationship between teachers' self-efficacy and self-esteem degree in the context of teaching efficacy.

\section{Method}

Participants: The participants were 200 primary teachers who were employed in the government run schools of primary education. The mean age of the subjects was $M=33.85$ years $S D=11.82$ with age range of 18 to 60 years of age.

Design: A 2 (self-efficacy: low vs. high) $\times 2$ (self-esteem: low vs. high) between subjects factorial design was used. The subjects were assigned randomly to the four treatment combinations.

Instruments Procedure:

Three questionnaires were utilized. The first was teachers' efficacy scale developed by Bandura. It consists of 30 self-report items which taps teachers' sense of efficacy to solve various hurdles in school and teaching (How much can you influence the decisions that are made in the school? How much can you do to keep students on 
task on difficult assignments?). The questionnaire contains seven subscales: efficacy to influence decision making, efficacy to influence school resources, instructional efficacy, disciplinary efficacy, efficacy to enlist parental involvement, efficacy to enlist community involvement, and efficacy to create a positive school climate. Each item is measured on a 9-point scale anchored with the notations: "nothing, very little, some influence, quite a bit, a great deal.” This measure attempts to provide a multi-faceted picture of teachers' efficacy beliefs without becoming too narrow or specific. In the present study, the alpha coefficient was .89 , hence indicating an internally reliable scale.

The second questionnaire was "general self-efficacy scale” (Schwarzer \& Jerusalem, 1995). It consists of 10 items which measures to assess a general sense of perceived self-efficacy (I can always manage to solve difficult problems if I try hard enough, I can usually handle whatever comes my way). Participants were asked to answer each item on 4-point scale: Not at all true, Hardly true, Moderately true, Exactly true. Ratings were assignes numerical values of 1 (Not at all true) to 4 (Exactly true). Subjects were asked to be as accurate as possible in giving the responses. Subjects were told that the information given by them will be confidential. The alpha of the scale was 0.61 which is supposed to be quite acceptable.

The third questinnaire was "self-esteem scale (Rosenberg, 1965). It consists of 10 items which was used to assess self-esteem. Respondents completed the scale by indicating their agreement with each of the 10 items (e.g. “On the whole I am satisfied with myself”, “I certainly feel useless at times”) on a 4-point scale (4 = strongly agree, 1 = strongly disagree). This gave a possible range of 10 - 40, with lower scores indicating greater selfworth. Reverse scoring was done for item number 2, 5, 68 and 9. In the present study, the alpha coefficient was 0.85 , hence indicating an internally reliable scale.

Higher score in self-efficacy indicates one's belief in one's ability and individual feels he/she is instrumental in completing task and achieving goals. Individuals high on self-efficacy put high degree of effort in order to meet their commitments, and attribute failure to things which are in their control, rather than blaming external factors. The low scores on general self-efficacy indicate that individual has no control of his/her life. On the basis of self-efficacy scale score, participants were divided into two groups-low-self-efficacy and high self-efficacy participants. The division self-efficacy into low and high was done on the basis of mean. Those who were above the mean were assigned as high on self-efficacy while those who were below were assigned as low on self-efficacy.

Similarly, scores on self-esteem was divided into low and high on self-efficacy. The low self-esteem indicates that individual has positive view about himself or herself while high self-esteem indicates negative image of individual.

All the participants were informed that there were no right and wrong answers. However, they were asked to be accurate in responding. They were assured the confidentiality of their identity and were informed that their answers would be used only for research purpose.

\section{Results}

Unless otherwise stated, only effects significant beyond at or 0.05 level are described. teachers' efficacy (efficacy to influence decision making, efficacy to influence school resources, instructional efficacy, disciplinary efficacy, efficacy to enlist parental involvement, efficacy to enlist community involvement, and efficacy to create a positive school climate), as within subject factor and general self-efficacy (low vs. high) and self-esteem (low vs. high) as between subject factor were utilized as within subject factors. The multivariate analysis of variance was utilized. The mean scores for each question type are shown in Table 1. Pictorial representation of the results is given in Figure 1.

A $2 \times 2$ (self-esteem X self-efficacy) factorial multivariate analysis of variance testes the effects of the selfesteem and the general self-efficacy on teachers' efficacy in primary schools. Teachers' efficacy scale has a seven components, namely, decision making, ability to influence school council/authority, perceived education self-efficacy, perceived disciplinary self-efficacy, ability to get cooperation from parents, ability to gather cooperation from parents, ability to gather cooperation from community, and ability to develop positive school environment.

Results indicated a significant main effect for the self-esteem, $\left\{F(1,196)=16.78, p<0.001, \eta^{2}=0.19\right\}$ as shown in Table 2.

As hypothesized, those who were on high self-esteem showed a higher teachers' efficacy $(\mathrm{M}=7.25, \mathrm{SD}=0.86)$ 


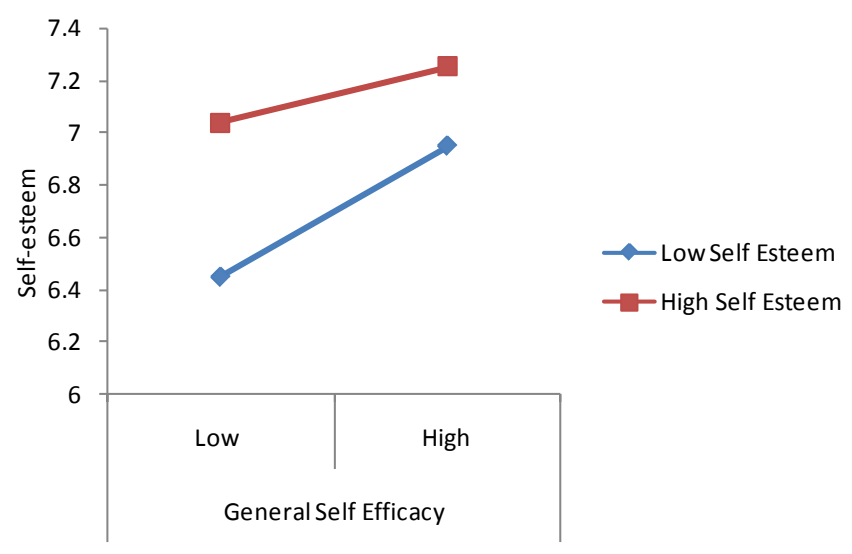

Figure 1. Self-esteem and general self-efficacy as a function of teachers' efficacy, $\mathrm{N}=200$.

Table 1. Means and (standard deviation) of self-efficacy and self-esteem meta-as a function of the category question.

\begin{tabular}{|c|c|c|c|c|c|c|c|c|c|c|c|c|c|c|}
\hline \multirow{3}{*}{$\begin{array}{l}\text { General } \\
\text { self- } \\
\text { efficacy }\end{array}$} & \multicolumn{14}{|c|}{ Teachers’ efficacy } \\
\hline & \multicolumn{2}{|c|}{ Decision making } & \multicolumn{2}{|c|}{$\begin{array}{l}\text { Ability to influence } \\
\text { school council/ } \\
\text { authorities }\end{array}$} & \multicolumn{2}{|c|}{$\begin{array}{l}\text { Perceived } \\
\text { education } \\
\text { self-efficacy }\end{array}$} & \multicolumn{2}{|c|}{$\begin{array}{l}\text { Perceived } \\
\text { disciplinary } \\
\text { self-efficacy }\end{array}$} & \multicolumn{2}{|c|}{$\begin{array}{c}\text { Ability to get } \\
\text { cooperation from } \\
\text { parents }\end{array}$} & \multicolumn{2}{|c|}{$\begin{array}{l}\text { Ability to gather } \\
\text { cooperation from } \\
\text { community }\end{array}$} & \multicolumn{2}{|c|}{$\begin{array}{c}\text { To develop } \\
\text { positive school } \\
\text { environment }\end{array}$} \\
\hline & $\begin{array}{c}\text { Low } \\
\text { self- } \\
\text { esteem }\end{array}$ & $\begin{array}{l}\text { High } \\
\text { self- } \\
\text { esteem }\end{array}$ & $\begin{array}{c}\text { Low } \\
\text { self- } \\
\text { esteem }\end{array}$ & $\begin{array}{l}\text { High } \\
\text { self- } \\
\text { esteem }\end{array}$ & $\begin{array}{c}\text { Low } \\
\text { self- } \\
\text { esteem }\end{array}$ & $\begin{array}{c}\text { High } \\
\text { self- } \\
\text { esteem }\end{array}$ & $\begin{array}{c}\text { Low } \\
\text { self- } \\
\text { esteem }\end{array}$ & $\begin{array}{l}\text { High } \\
\text { self- } \\
\text { esteem }\end{array}$ & $\begin{array}{c}\text { Low } \\
\text { self- } \\
\text { esteem }\end{array}$ & $\begin{array}{l}\text { High } \\
\text { self- } \\
\text { esteem }\end{array}$ & $\begin{array}{l}\text { Low } \\
\text { self- } \\
\text { esteem }\end{array}$ & $\begin{array}{l}\text { High } \\
\text { self- } \\
\text { esteem }\end{array}$ & $\begin{array}{c}\text { Low } \\
\text { self- } \\
\text { esteem }\end{array}$ & $\begin{array}{c}\text { High } \\
\text { self- } \\
\text { esteem }\end{array}$ \\
\hline Low & $\begin{array}{c}4.16 \\
(0.82)\end{array}$ & $\begin{array}{c}5.27 \\
(1.79)\end{array}$ & $\begin{array}{c}7.62 \\
(1.39)\end{array}$ & $\begin{array}{c}7.53 \\
(1.48)\end{array}$ & $\begin{array}{c}6.86 \\
(1.07)\end{array}$ & $\begin{array}{c}7.43 \\
(0.95)\end{array}$ & $\begin{array}{c}7.34 \\
(1.02)\end{array}$ & $\begin{array}{c}7.73 \\
(0.92)\end{array}$ & $\begin{array}{c}6.74 \\
(1.23)\end{array}$ & $\begin{array}{c}7.31 \\
(1.07)\end{array}$ & $\begin{array}{c}4.92 \\
(1.77)\end{array}$ & $\begin{array}{c}5.83 \\
(1.82)\end{array}$ & $\begin{array}{c}7.13 \\
(1.54)\end{array}$ & $\begin{array}{c}7.78 \\
(1.23)\end{array}$ \\
\hline High & $\begin{array}{c}4.58 \\
(1.02)\end{array}$ & $\begin{array}{c}5.20 \\
(1.36)\end{array}$ & $\begin{array}{c}7.84 \\
(1.64)\end{array}$ & $\begin{array}{c}7.60 \\
(1.45)\end{array}$ & $\begin{array}{c}7.30 \\
(0.85)\end{array}$ & $\begin{array}{c}7.89 \\
(0.77)\end{array}$ & $\begin{array}{c}7.97 \\
(0.77)\end{array}$ & $\begin{array}{c}8.19 \\
(0.83)\end{array}$ & $\begin{array}{c}7.41 \\
(1.08)\end{array}$ & $\begin{array}{c}7.43 \\
(1.33)\end{array}$ & $\begin{array}{c}5.68 \\
(1.84)\end{array}$ & $\begin{array}{c}6.20 \\
(1.98)\end{array}$ & $\begin{array}{c}7.57 \\
(1.34)\end{array}$ & $\begin{array}{c}8.17 \\
(1.34)\end{array}$ \\
\hline
\end{tabular}

$\mathrm{N}=200$.

Table 2. Summary of multivariate analysis of variance of performance scores on self-esteem (low vs high), and general self-efficacy (low vs high). Tests of between-subjects effects.

\begin{tabular}{|c|c|c|c|c|c|c|c|c|c|}
\hline Source & $\begin{array}{l}\text { Dependent } \\
\text { Variable }\end{array}$ & $\begin{array}{l}\text { Type III Sum of } \\
\text { Squares }\end{array}$ & df & Mean Square & $\mathrm{F}$ & Sig. & $\begin{array}{l}\text { Partial Eta } \\
\text { Squared }\end{array}$ & $\begin{array}{l}\text { Noncent. } \\
\text { Parameter }\end{array}$ & $\begin{array}{l}\text { Observed } \\
\text { Power }^{\mathrm{b}}\end{array}$ \\
\hline \multirow{6}{*}{ Corrected Model } & DMAvg & $19.526^{\mathrm{a}}$ & 2 & 9.763 & 6.402 & 0.002 & 0.061 & 12.805 & 0.899 \\
\hline & SCAvg & $1.860^{c}$ & 2 & 0.930 & 0.430 & 0.651 & 0.004 & 0.860 & 0.119 \\
\hline & EduPerAvg & $33.521^{d}$ & 2 & 16.761 & 19.492 & 0.000 & 0.165 & 38.983 & 1.000 \\
\hline & CPAvg & $16.180^{f}$ & 2 & 8.090 & 5.506 & 0.005 & 0.053 & 11.011 & 0.847 \\
\hline & PCAvg & $52.752^{\mathrm{g}}$ & 2 & 26.376 & 7.660 & 0.001 & 0.072 & 15.320 & 0.945 \\
\hline & PEnvtAvg & $34.283^{h}$ & 2 & 17.142 & 8.890 & 0.000 & 0.083 & 17.781 & 0.971 \\
\hline \multirow{5}{*}{ Intercept } & DMAvg & 4802.448 & 1 & 4802.448 & 3.149E3 & 0.000 & 0.941 & 3149.277 & 1.000 \\
\hline & EduPerAvg & 10813.322 & 1 & 10813.322 & $1.258 \mathrm{E} 4$ & 0.000 & 0.985 & 12575.293 & 1.000 \\
\hline & DiscAvg & 12107.274 & 1 & 12107.274 & $1.492 \mathrm{E} 4$ & 0.000 & 0.987 & 14918.048 & 1.000 \\
\hline & CPAvg & 10295.719 & 1 & 10295.719 & 7.007E3 & 0.000 & 0.973 & 7006.865 & 1.000 \\
\hline & PCAvg & 6318.377 & 1 & 6318.377 & 1.835E3 & 0.000 & 0.903 & 1835.002 & 1.000 \\
\hline
\end{tabular}




\begin{tabular}{|c|c|c|c|c|c|c|c|c|c|}
\hline \multicolumn{10}{|l|}{ Continued } \\
\hline & PEnvtAvg & 11675.854 & 1 & 11675.854 & $6.056 \mathrm{E} 3$ & 0.000 & 0.968 & 6055.611 & 1.000 \\
\hline & DMAvg & 18.848 & 1 & 18.848 & 12.360 & 0.001 & 0.059 & 12.360 & 0.938 \\
\hline & SCAvg & 1.240 & 1 & 1.240 & .573 & 0.450 & 0.003 & 0.573 & 0.117 \\
\hline & EduPerAvg & 15.691 & 1 & 15.691 & 18.248 & 0.000 & 0.085 & 18.248 & 0.989 \\
\hline \multirow[t]{7}{*}{ Self-Esteem } & DiscAvg & 4.379 & 1 & 4.379 & 5.395 & 0.021 & 0.027 & 5.395 & 0.637 \\
\hline & CPAvg & 4.199 & 1 & 4.199 & 2.857 & 0.093 & 0.014 & 2.857 & 0.391 \\
\hline & PCAvg & 23.919 & 1 & 23.919 & 6.947 & 0.009 & 0.034 & 6.947 & 0.746 \\
\hline & PEnvtAvg & 17.989 & 1 & 17.989 & 9.330 & 0.003 & 0.045 & 9.330 & 0.860 \\
\hline & DMAvg & 0.106 & 1 & 0.106 & .069 & 0.792 & 0.000 & 0.069 & 0.058 \\
\hline & SCAvg & 1.098 & 1 & 1.098 & .508 & 0.477 & 0.003 & 0.508 & 0.109 \\
\hline & EduPerAvg & 9.340 & 1 & 9.340 & 10.862 & 0.001 & 0.052 & 10.862 & 0.907 \\
\hline \multirow[t]{7}{*}{$\begin{array}{c}\text { General } \\
\text { Self-Efficacy }\end{array}$} & DiscAvg & 13.832 & 1 & 13.832 & 17.043 & 0.000 & 0.080 & 17.043 & 0.984 \\
\hline & CPAvg & 7.923 & 1 & 7.923 & 5.392 & 0.021 & 0.027 & 5.392 & 0.637 \\
\hline & PCAvg & 15.400 & 1 & 15.400 & 4.473 & 0.036 & 0.022 & 4.473 & 0.557 \\
\hline & PEnvtAvg & 7.863 & 1 & 7.863 & 4.078 & 0.045 & 0.020 & 4.078 & 0.520 \\
\hline & DMAvg & 300.412 & 197 & 1.525 & & & & & \\
\hline & SCAvg & 426.220 & 197 & 2.164 & & & & & \\
\hline & EduPerAvg & 169.398 & 197 & 0.860 & & & & & \\
\hline \multirow[t]{7}{*}{ Error } & DiscAvg & 159.882 & 197 & 0.812 & & & & & \\
\hline & CPAvg & 289.467 & 197 & 1.469 & & & & & \\
\hline & PCAvg & 678.321 & 197 & 3.443 & & & & & \\
\hline & PEnvtAvg & 379.837 & 197 & 1.928 & & & & & \\
\hline & DMAvg & 5107.250 & 200 & & & & & & \\
\hline & SCAvg & 12102.000 & 200 & & & & & & \\
\hline & EduPerAvg & 10984.646 & 200 & & & & & & \\
\hline \multirow[t]{7}{*}{ Total } & DiscAvg & 12279.893 & 200 & & & & & & \\
\hline & CPAvg & 10595.603 & 200 & & & & & & \\
\hline & PCAvg & 7002.176 & 200 & & & & & & \\
\hline & PEnvtAvg & 12057.500 & 200 & & & & & & \\
\hline & DMAvg & 319.939 & 199 & & & & & & \\
\hline & SCAvg & 428.080 & 199 & & & & & & \\
\hline & EduPerAvg & 202.919 & 199 & & & & & & \\
\hline \multirow[t]{4}{*}{ Corrected Total } & DiscAvg & 183.702 & 199 & & & & & & \\
\hline & CPAvg & 305.647 & 199 & & & & & & \\
\hline & PCAvg & 731.072 & 199 & & & & & & \\
\hline & PEnvtAvg & 414.120 & 199 & & & & & & \\
\hline
\end{tabular}

DMavg = Efficacy to influence decision making; SCAvg = Efficacy to influence school council/authorities; EduPerAvg = Percieved education self-efficacy; DiscAvg = Perceived disciplinary self-efficacy; CPAvg = Ability to get cooperation from parents; PCAvg = Ability to gather cooperation from community; PEnvtAvg = Efficacy develop positive school environment. 
compared to those who were low on self-esteem $(\mathrm{M}=6.63, \mathrm{SD}=0.88)$. There was also a significant main effect of self-efficacy $\left\{F(1,196)=11.01, p<0.001, \eta^{2}=0.10\right\}$. Teachers with high on self-efficacy showed better performance on teaching efficacy $(M=7.21$, $S D=0.88)$ than those who were low on self-efficacy $(M=6.65$, $\mathrm{SD}=0.89$ ). However, no significant interaction between self-esteem and self-efficacy was found. As mentioned earlier, teachers' efficacy has seven components. However, not all the components were significant? Self-esteem influenced only in decision making, perceived education self-efficacy, perceived disciplinary self-efficacy, ability to get cooperation from community, and in the development of positive school environment. General selfefficacy influenced all the components except decision making and ability to influence school council/ authorities. There was a positive and significant correlation between teachers' self-efficacy and general self-efficacy $(\mathrm{r}=$ $0.29, p<0.001$ ). Similarly, positive and significant correlation was revealed by bivariate correlation analysis between teachers' efficacy and self-esteem. Self-esteem and general self-efficacy also showed positive and significant correlation.

\section{Discussion and Conclusion}

Belief in one's capacity to change a given situation or successfully perform a task is one of the determining factors in self-esteem (Branden, 1969). General self-efficacy is not the same as self-efficacy. Self-efficacy is task specific and malleable. On the other hand general self-efficacy is generalized competence belief to perform any task. There is powerful effect of teachers' beliefs in his or her ability to positively impact student learning. It is very critical in actual success or failure in teachers' behaviour. Gibson and Dembo (1984) found that teachers with high efficacy devote more classroom time to academic learning, praise students for accomplishments and helps them to succeed. On the other hand, teachers with low sense of efficacy spend more time on non-academic pass time, give up on students if they do not give results and criticize them for failure.

Research in teachers' efficacy is growing rapidly recently. This study was an attempt at understanding role of self-esteem and general self-efficacy in teachers' efficacy. It was found that low self-esteem and low general self-efficacy led to low teachers' efficacy and consequently substandard performance in the class. On the contrary, high teachers' efficacy was a reflection of high self-esteem and high general self-efficacy. In the study, it was observed that self-esteem significantly influenced teachers' efficacy. The finding showed that self-esteem has a causal relationship with teachers' efficacy. Similarly, general self-efficacy also affected teachers' efficacy which is obvious because general self-efficacy influences behavior in general. However, there was no significant interaction effect of self-esteem and general self-efficacy on teachers' efficacy that was quite surprising. Moreover, there were positive and significant correlations between teachers' efficacy and general self-efficacy ( $\mathrm{r}=$ $0.29, p<0.001)$, and teachers' efficacy and self-esteem $(r=0.38, p<0.001)$.

The current study has a few limitations. First, it is very difficult to fathom teachers' efficacy just by looking at self-esteem and general self-efficacy. There is a need to include more psychological components to understand teachers' efficacy in totality. Second, self-report questionnaires are susceptible to answers colored with social desirability. Results of this study should, therefore, be interpreted with caution.

\section{References}

Allinder, R. M. (1994). The Relationships between Efficacy and the Instructional Practices of Special Education Teachers and Consultants. Teacher Education and Special Education, 17, 86-95. http://dx.doi.org/10.1177/088840649401700203

Anderson, R., Greene, M., \& Loewen, P. (1988). Relationships among Teachers’ and Students’ Thinking Skills, Sense of Efficacy, and Student Achievement. Alberta Journal of Educational Research, 34, 148-165.

Ashton, P. T, \& Webb, R. B. (1986). Making a Difference: Teachers' Sense of Efficacy and Student Achievement. New York: Longman.

Ashton, P. T. \& Webb, R. (1982). Teachers’ Sense of Efficacy: Toward an Ecological Model. New York: Annual Meeting of the American Educational Research Association.

Bandura, A. (1983). Self-Efficacy Determinants of Anticipated Fears and Calamities. Journal of Personality and Social Psychology, 45, 464-469. http://dx.doi.org/10.1037/0022-3514.45.2.464

Bandura, A. (1997). Self-Efficacy: The Exercise of Control. New York: W. H. Freeman.

Bergman, P., McLaughlin, M., Bass, M., Pauly, E., \& Zellman, G. (1977). Federal Programs Supporting Educational Change: Vol. VII. Factors Affecting Implementation and Continuation. ERIC Document Reproduction Service No. 140 432, Santa Monica, CA: RAND. 
Berman, P., \& McLaughlin, M. W. (1977). Federal Programs Supporting Educational Change, Volume VII: Factors Affecting Implementation and Continuation. Santa Monica, CA: The RAND Corporation.

Bowles, S., \& Gintis, H. (1976). Schooling in Capitalist America. New York: Basic Books, Inc.

Bowles, S., Gintis, H., \& Osborne, M. (2001). The Determinants of Earnings: A Behavioural Approach. Journal of Economic Literature, 39, 1137-1176. http://dx.doi.org/10.1257/jel.39.4.1137

Branden, N. (1969). The Psychology of Self-Esteem: A New Concept of Mans Psychological Nature. Los Angeles, CA: Nash Publishing.

Coladarci, T. (1992). Teachers' Sense of Efficacy and Commitment to Teaching. Journal of Experimental Education, 60, 323-337. http://dx.doi.org/10.1080/00220973.1992.9943869

Davis, F. W., \& Yates, B. T. (1982). Self-Efficacy Expectancies versus Outcome Expectancies as Determinants of Performance Deficits and Depressive Affect. Cognitive Therapy and Research, 6, 23-35. http://dx.doi.org/10.1007/BF01185724

Evers, W. J. G., Brouwers, A., \& Tomic, W. (2002). Burnout and Self-Efficacy: A Study on Teachers' Beliefs when Implementing an Innovative Educational System in the Netherlands. British Journal of Educational Psychology, 72, 227-243. http://dx.doi.org/10.1348/000709902158865

Garcia, M. E., Schmitz, J. M., \& Doerfler, L. A. (1990). A Fine-Grained Analysis of the Role of Self-Efficacy in Self-Initiated Attempts to Quit Smoking. Journal of Consulting and Clinical Psychology, 58, 317-322. http://dx.doi.org/10.1037/0022-006X.58.3.317

Gibson, S., \& Dembo, M. (1984). Teacher Efficacy: A Construct Validation. Journal of Educational Psychology, 76, 569582. http://dx.doi.org/10.1037/0022-0663.76.4.569

Guskey, T. R. (1988). Teacher Efficacy, Self-Concept, and Attitudes toward the Implementation of Instructional Innovation. Teaching and Teacher Education, 4, 63-69. http://dx.doi.org/10.1016/0742-051X(88)90025-X

Henson, R. K. (2001). The Effects of Participation in Teacher Research on Teacher Efficacy. Teaching and Teacher Education, 17, 819-836. http://dx.doi.org/10.1016/S0742-051X(01)00033-6

Hogg, M. A., \& Vaughan, G. M. (2002). Social Psychology (3rd ed.). London: Prentice Hall.

Kohn, A. (1994). The Truth about Self-Esteem. Phi Delta Kappan, 76, 272-283.

Meijer, C., \& Foster, S. (1988). The Effect of Teacher Self-Efficacy on Referral Chance. Journal of Special Education, 22, 378-385. http://dx.doi.org/10.1177/002246698802200309

Midgley, C., Feldlaufer, H., \& Eccles, J. (1989). Change in Teacher Efficacy and Student Self- and Task-Related Beliefs in Mathematics during the Transition to Junior High School. Journal of Educational Psychology, 81, 247-258. http://dx.doi.org/10.1037/0022-0663.81.2.247

Pajares, F. (1997). Current Directions in Self-Efficacy Research. In M. Maehr, \& P. R. Pintrich (Eds.), Advances in Motivation and Achievement (Vol. 10, pp. 1-49). Greenwich, CT: JAI Press.

Pintrich, P. R., \& De Groot, V. (1990). Motivational and Self-Regulated Learning Components of Classroom Academic Performance. Journal of Educational Psychology, 82, 33-40. http://dx.doi.org/10.1037/0022-0663.82.1.33

Podell, D., \& Soodak, L. (1993). Teacher Efficacy and Bias in Special Education Referrals. Journal of Educational Research, 86, 247-253. http://dx.doi.org/10.1080/00220671.1993.9941836

Rosenberg, M. (1965). Society and the Adolescent Self-Image. Princeton, NJ: Princeton University Press.

Ross, J. A. (1992). Teacher Efficacy and the Effect of Coaching on Student Achievement. Canadian Journal of Education, 17, 51-65. http://dx.doi.org/10.2307/1495395

Rotter, J. B. (1966). Generalised Expectancies for Internal versus External Control of Reinforcement. Psychological Monographs, 80, 1-28. http://dx.doi.org/10.1037/h0092976

Saklofske, D. H., Michayluk, J. O., \& Randhawa, B. S. (1988). Teachers’ Efficacy and Teaching Behaviours. Psychological Reports, 63, 407-414. http://dx.doi.org/10.2466/pr0.1988.63.2.407

Schunk, D. (1985). Self-Efficacy and School Learning. Psychology in the Schools, 22, 208-223. http://dx.doi.org/10.1002/1520-6807(198504)22:2<208::AID-PITS2310220215>3.0.CO;2-7

Schwarzer, R., \& Jerusalem, M. (1995). Generalized Self-Efficacy Scale. In J. Weinman, S. Wright, \& M. Johnston (Eds.), Measures in Health Psychology: A User's Portfolio. Causal and Control Beliefs (pp. 35-37). Windsor: NFER-NELSON.

Stein, M. K., \& Wang, M. C. (1988). Teacher Development and School Improvement: The Process of Teacher Change. Teaching and Teacher Education, 4, 171-187. http://dx.doi.org/10.1016/0742-051X(88)90016-9

Vancouver Community Network (1998). Self-Esteem. http://www.vcn.bc.ca/rmdcmha/esteem.htm

Watson, S. (1991). A Study of the Effects of Teacher Efficacy on Academic Achievement of Third-Grade Students in Selected Elementary Schools in South Carolina. Unpublished Doctoral Dissertation, Orangeburg, SC: South Carolina State Col- 
lege.

Wenzel, S. L. (1993). The Relationship of Psychological Resources and Social Support to Job Procurement Self-Efficacy in the Disadvantaged. Journal of Applied Psychology, 23, 1471-1497.

Woolfolk, A. E., \& Hoy, W. K. (1990). Prospective Teachers' Sense of Efficacy and Beliefs about Control. Journal of Educational Psychology, 82, 81-91. http://dx.doi.org/10.1037/0022-0663.82.1.81

Woolfolk, A. E., Rosoff, B., \& Hoy, W. K. (1990). Teachers’ Sense of Efficacy and Their Beliefs about Managing Students. Teaching \& Teacher Education, 6, 137-148. http://dx.doi.org/10.1016/0742-051X(90)90031-Y 
Scientific Research Publishing (SCIRP) is one of the largest Open Access journal publishers. It is currently publishing more than 200 open access, online, peer-reviewed journals covering a wide range of academic disciplines. SCIRP serves the worldwide academic communities and contributes to the progress and application of science with its publication.

Other selected journals from SCIRP are listed as below. Submit your manuscript to us via either submit@scirp.org or Online Submission Portal.
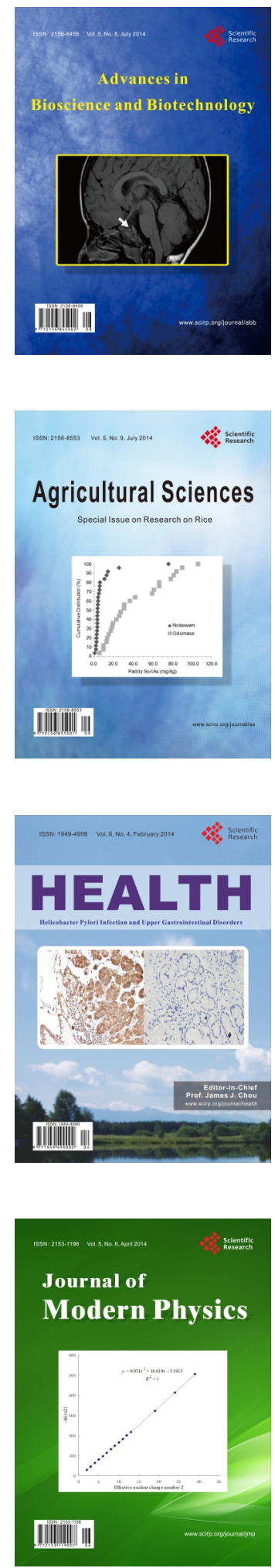
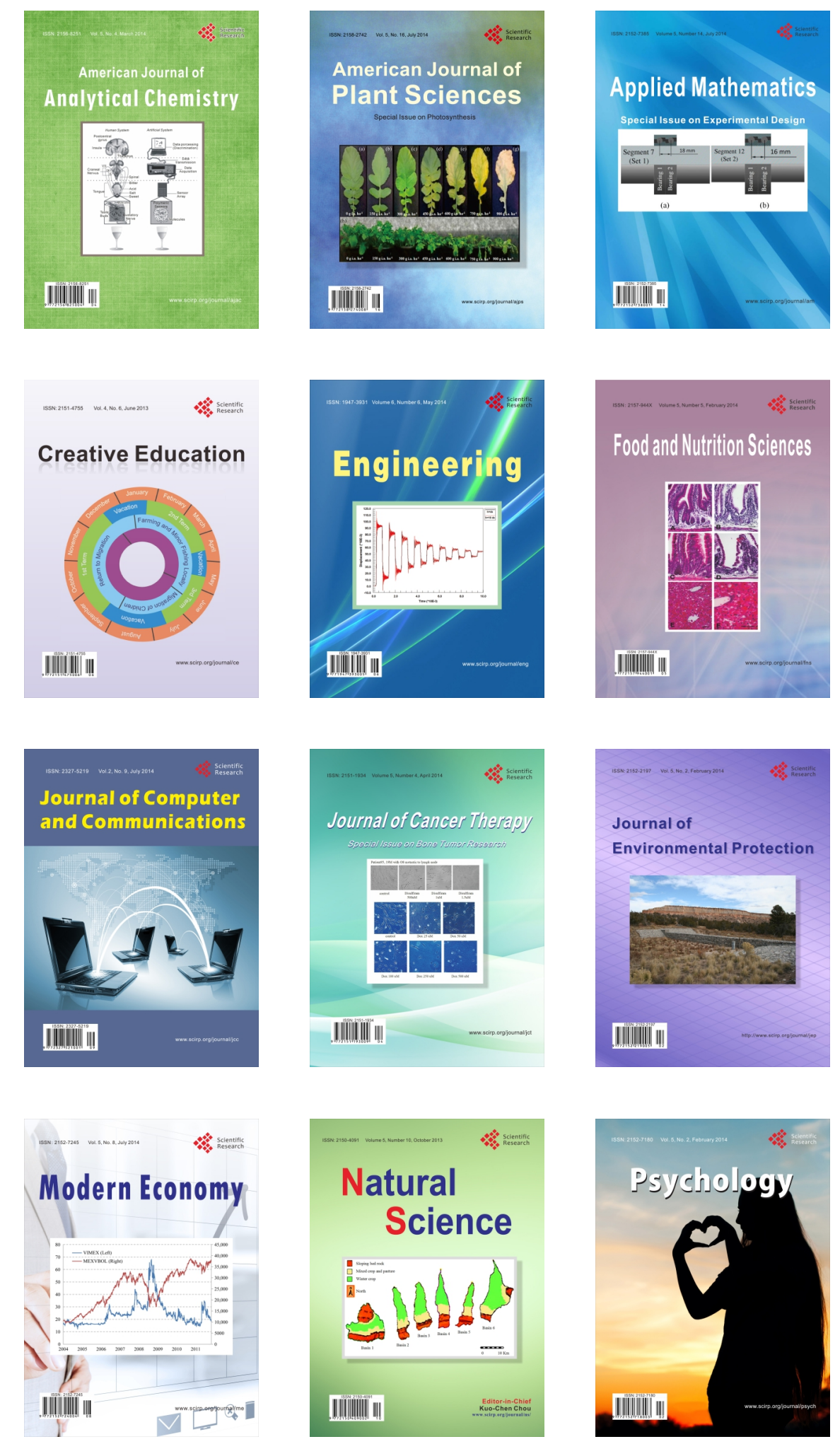